must be settled by future research. The purpose of the present paper is only to draw the attention of investigators to the fact that the use of a minute quantity of typhus virus, not attenuated by a special method, can harmlessly confer upon an animal a prophylactic power against the virus. It is sincerely hoped that this discovery may throw some light on the prevention of those diseases which have invisible viruses as their agency.

\section{SOME OBSERVATIONS ON}

BASAL METABOLISM IN MENSTRUATION.

\section{By MARION O. P. WILTSHIRE, B.Sc.}

(From the Physiology Laboratory, London (R.F.H.) School of Medicine for Women.)

THE theory that the life processes of women undergo a periodic variation correlated with menstruation has been suggested by many writers and was emphasised as long ago as 1876 by Jacobi, and again by Goodman in 1878. Since then the effect of menstruation on the life processes of women has been studied in various ways. The lines along which these investigations have proceeded include observations on the temperature, pulse-rate, blood pressure, the metabolism of nitrogen, phosphorus, and calcium, the excretion of creatine, and the $\mathrm{CO}_{2}$ output and $\mathrm{O}_{2}$ consumption. The results recorded are extremely conflicting, but the later, and probably more accurate, observations all point to the fact that, with the possible exception of temperature and perhaps also of pulse-rate, there is no periodic variation in any of these values. In the case of temperature most workers agree that there are slight but definite periodic changes correlated with menstruation.

In view of these conflicting results it was decided to undertake yet another series of experiments comparing the physiological processes in the menstrual and inter-menstrual periods. The points chosen for determination were : (1) the basal metabolic rate of normal women during menstruation and between menstrual periods; and also at these times (2) the cost to the organism of a certain definite piece of work, and (3) the rate of recovery from that work.

(1) Observations were made on five subjects, the basal metabolism being determined, as far as possible, each day during the menstrual periods and three or four times between these periods. In three cases the subjects came to the laboratory about $8 \mathrm{~A} . M$., in the post-absorptive condition, and lay down for half an hour before the experiment began. A five-minute sample of expired air was collected in a bag, measured, and analysed by means of the Brodie gas analysis apparatus. Of the other two subjects more numerous observations were made, and the samples collected while they were still in bed. The height and weight of each subject were determined, and the surface area read off from a $\mathrm{Du}$ Bois height-weight chart. From these data, the $\mathrm{O}_{2}$ consumption per minute per sq. m. of body surface was calculated, and Table $\mathbf{r}$. gives the average results for each subject for the different phases of the monthly cycle.

TABLE $\mathbf{I}$.

\begin{tabular}{|c|c|c|c|c|c|c|}
\hline \multirow{2}{*}{ Subject. } & \multirow{2}{*}{$\begin{array}{c}\text { No. of } \\
\text { periods } \\
\text { covered by } \\
\text { observations. }\end{array}$} & \multirow{2}{*}{$\begin{array}{l}\text { Total No. } \\
\text { of observa- } \\
\text { tions. }\end{array}$} & \multicolumn{4}{|c|}{$\begin{array}{l}\text { C.cm. } \mathrm{O}_{2} \text { consumed } \\
\text { per sq.m. per min. }\end{array}$} \\
\hline & & & $\begin{array}{c}\text { Pre- } \\
\text { menst. }\end{array}$ & Menst. & $\begin{array}{l}\text { Post. } \\
\text { menst. }\end{array}$ & $\begin{array}{l}\text { Inter } \\
\text { menst }\end{array}$ \\
\hline $\begin{array}{l}\text { I. } \\
\text { III. } \\
\text { IIV. } \\
\text { V. }\end{array}$ & $\begin{array}{l}5 \\
4 \\
4 \\
6 \\
2\end{array}$ & $\begin{array}{l}39 \\
25 \\
29 \\
58 \\
33\end{array}$ & $\begin{array}{l}139 \\
144 \\
140 \\
116 \\
111\end{array}$ & $\begin{array}{l}139 \\
143 \\
140 \\
109 \\
114\end{array}$ & $\begin{array}{l}145 \\
141 \\
132 \\
109 \\
117\end{array}$ & $\begin{array}{l}146 \\
142 \\
139 \\
116 \\
116\end{array}$ \\
\hline
\end{tabular}

When the results are expressed in this way the respiratory quotient (R.Q.) is not taken into consideration. As this was found to be variable and not constant, as is frequently assumed, the calorie value per sq. m. per hour was calculated, taking the R.Q. into account. These results are given in Table II. TABLE IT.

\begin{tabular}{c|c|c|c|c}
\hline \multirow{2}{*}{ Subject. } & \multicolumn{3}{|c|}{ Caloric value per sq.m. per hour. } \\
\cline { 2 - 4 } & Pre-menst. & Menst. & Post-menst. & Inter-menst. \\
\hline II. & $40 \cdot 7$ & $40 \cdot 2$ & $40 \cdot 4$ & $40 \cdot 9$ \\
II. & $40 \cdot 4$ & $40 \cdot 4$ & $40 \cdot 5$ & $39 \cdot 8$ \\
III. & $40 \cdot 2$ & $40 \cdot 8$ & $38 \cdot 9$ & $40 \cdot 3$ \\
IV. & $33 \cdot 5$ & $31 \cdot 3$ & $31 \cdot 5$ & $33 \cdot 1$ \\
V. & $32 \cdot 2$ & $32 \cdot 5$ & $32 \cdot 8$ & $32 \cdot 2$ \\
\hline
\end{tabular}

It will be noticed that the inter-menstrual values vary considerably in the different subjects, although the mean value, $37 \cdot 2$, agrees with that given by Benedict as an average value for women. The variations during the different phases of the sexual cycle are so small that they cannot be regarded as showing any marked effect due to menstruation; the fluctuations which normally occur are often greater than these variations. This conclusion agrees with that recently expressed by Blunt and Dye, but it is not in accordance with the view put forward by Snell, Ford, and Rowntree. These observers, in a preliminary communication which appeared last year, expressed the belief that menstruation "does affect the basal metabolic rate in women at times in health and in disease."

(2) and (3) Although the results obtained show that the basal metabolism is not appreciably affected by menstruation, it seemed possible that the cost of work to the organism during the menstrual period might differ from that during the inter-menstrual period. Consequently a few determinations have been made to test this possiblity, and although these experiments are not yet completed, the method and an example of the results obtained are included here. A certain definite piece of work was performed on days during the menstrual period and again during the intermenstrual period. The amount of exercise is very much less than that performed in the experiments of Krogh and Lindhard, and of Douglas, Campbell, and Hobson, on the subject of respiratory changes during work and rest. This small amount of exercise was selected as it was found that the subject could undertake it without any real physical fatigue; with greater amounts this was not so. The work consisted in stepping up and down on a low stool in time with a metronome; the exercise lasted for three minutes, 36 steps per minute were taken, the stool being $6 \frac{1}{2}$ in. high. The basal metabolism was first determined in the usual manner, and then, after the subject had been standing for about five minutes, a half-minute sample of expired air was taken before exercise began. During the exercise half-minute samples of expired air were collected during the first half of each minute. After the cessation of exercise the subject remained standing and half-minute samples of expired air were collected during the first three minutes, and then during the fifth, seventh, ninth, and eleventh minutes, by which time it was found that the metabolism was restored to normal. The $\mathrm{O}_{2}$ intake and $\mathrm{CO}_{2}$ output for each of the half-minutes were determined and the results are given in the graphs, Fig. I. being a result obtained during the inter-menstrual period, and Fig. II. during the menstrual period. These indicate that the cost of work and the rate of recovery from work are the same during the menstrual and inter-menstrual periods. In both cases there is a sharp rise in the $\mathrm{CO}_{2}$ output and $\mathrm{O}_{2}$ intake during exercise, followed by a gradual return to the resting value when work ceases. The greatest drop occurs during the first two minutes of rest, the fall after this being much more gradual. The variations in the R.Q. are interesting. Whilst the work is being done the R.Q. falls at first, usually being lowest during the second minute of work with a tendency to recover during the third minute of work. After cessation of work the R.Q. rises very rapidly, 
is usually highest during the second minute of rest, and then falls slowly to normal with perhaps slight fluctuations. Although more of these experiments must be done before any definite conclusion can be drawn, the processes appear to be identical during the menstrual and inter-menstrual periods.

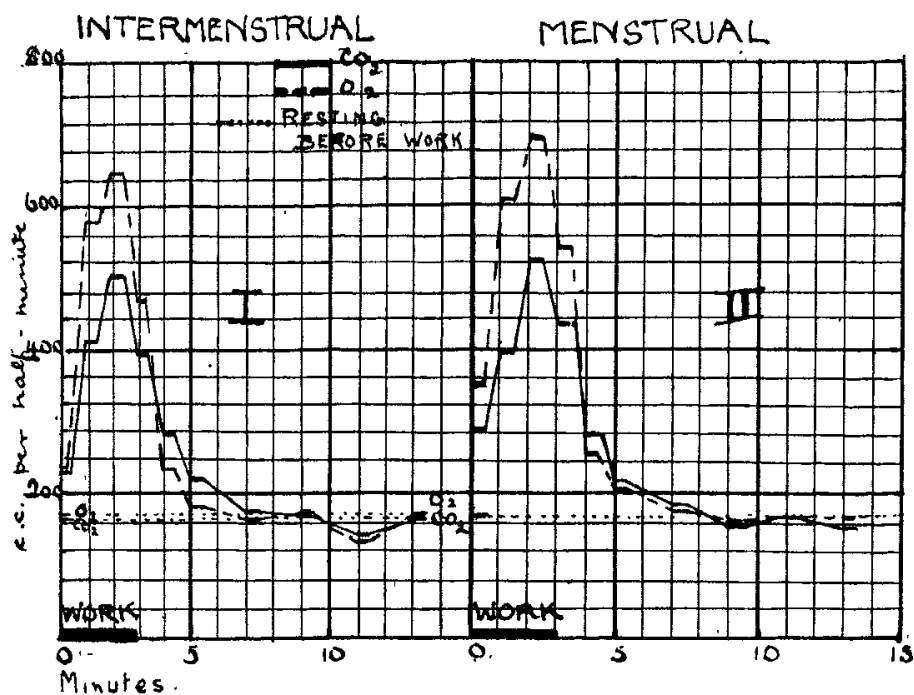

In conclusion, I wish to thank Prof. Winifred Cullis for suggesting to me this piece of work and for help and criticism during the work, and the Industrial Fatigue Research Board for the purchase of some of the necessary apparatus. I should also like to thank most warmly the subjects of the observations for their coöperation over a long period.

\section{Bibliography.}

Jacobi : The Question of Rest for Women during Menstrua tion, Boylston Prize Essay, 1876.

Goodman: Cyclical Theory of Menstruation, Amer. Jour. obstet., 1878 , ii., 673 .

Giles: The Cyclical or Wave Theory of Menstruation, Obstet. Trans., 1897, xxxix., 115.

King: Concerning the Periodic Cardiovascular and Tem203 .

I Zuntz: Ueber den Finfluss der Ovarien auf den Stoffwechsel, Archiv. für Gynaek., 1906, lxxviii 106.

Blair Bell: Menstruation and its Relationship to Calcium Metabolism, Proc. Roy. Soc Med., 1908.

Sherman, Gillett, and Pope : Monthly Mretabolism of Nitrogen Phosphorus, and Calcium in Healthy KT

1918, xxxiv., 372 . Healthy Women, Amer. Jour. Phys., 1918, xlvii., 25.

Krause: Quar. Jour. Exper. Phys., 1911, iv., 293; 1914 vii., 87 .

M. S. Rose: Creatinuria in Women, Jour. Biol. Chem. 1917 . xxil

Gtearns and $r$ sis. Diet and Sex as Factors in the Creatinuria of Man, Amer. Jour. Phys., 1921, lvi., 60

Blunt and Dye: Basal IIetabolism in Normal Wornen, Jour. Biol. Chem., 1921, xlvii., 69.

Snell, Ford, and Rowntree: Studies in Basal Metabolism, Jour. Snell, Ford, and Rowntree: Studies
Amer. Med. Assoc., 1920, lxxv., 515 .

Krogh and Lindhard: Changes in Respiration at the TransKrogh and lindhard: Changes in Respiration at the

Campbell, Douglas, and Hobson : The Respiratory Exchange of Man during and after Muscular Hercise, Proc. Roy. Soc., 1920 , Series B., ccx., 1 .

The Late Prof. G. T. Ladd. The death is announced at Newhaven, Connecticut, of George Trumbull Ladd, A.M., D.D., LL.D., emeritus professor of mental and moral philosophy, Yale University, author of "Elements of Physiological Psychology" and many other theological, philosophical, and psychological works.

Portsmouth Venereal Diseases Notices.-The affixing in public lavatories of notices giving instruction as to prevention of venereal diseases was discussed on August 9th at a meeting of the Portsmouth Town Council, when certain members of the council expressed their strong disapproval of the practice, stating their belief that it was an offence against decency, and that the notices were shameful and disgraceful. other members pointed out that a visitor from the Ministry of Health had recently been to Portsmouth and had found no fault with the council's action in the matter; moreover, that action had been approved by a large conference of all the leading organisations of the town.
BRITISH MEDIC $\Lambda \mathrm{T}, \triangle$ SSOCTATION. ANNUAI، MEETING $\Lambda$ T NEWCASTLE-ON-TYNE.

\section{SECTION OF ORTHOPADDICS $\Lambda$ ND DISEASES} OF CIIILDREN.

\section{WEDNESDAY, JULY 20'TH.}

At the first session, Mr. A. II. TuBBY, the President, being in the chair, a discussion on the

\section{Early Diagnosis and Treatment of Anterior Poliomyelitis}

was opened by Dr. E. F. Buzzard (London), who emphasised some of the frequent mistakes made in the diagnosis in the initial stages of this disease. He considered that given a more widespread recognition of the conception of acute poliomyelitis as one of the specific fevers of childhood, the clinician should be able to arrive at an early diagnosis with greater frequency. It was to be remembered that, contrary to the ordinary accepted teaching, pain was often a prominent symptom of the onset. Confusion sometimes arose in connexion with the resemblance of this disease to other acute infective conditions of the nervous system-viz., meningitis, toxic polyneuritis, Landry's paralysis, myelitis, and lethargic encephalitis. By careful examination it was usually possible to avoid errors from a clinical survey of the patient alone. A serological diagnostic test was theoretically available, but owing to the time involved was of little practical use. In approaching the early treatment of poliomyelitis it was essential to visualise the morbid anatomy of the disease. Treatment might be conveniently discussed under three headings representing stages in the progress of the condition: (1) the treatment of the patient who is ill with the disease, (2) the treatment of the patient during convalescence; and (3) the treatment of the resulting disabilities. During the first two stages a policy of inactivity, supplemented by several well-defined active measures, was indicated. The pyrexia and pain should be treated on the usual lines; in an epidemic, an immune serum, if available, should be given a trial, and the routine use of hexamine, although of doubtful efficacy, was to be regarded as reasonable. Physiological rest, however, was the great essential, and combined with it, the adoption of correct postures for the patient as a whole and for each portion of the body. The paralysed parts should be kept warm and their local circulation promoted by light rubbing. For about 18 months after the onset of paralysis varying degrees of recovery of function in muscles could be expected. This period was one of probation, and should be occupied by the continuance of muscle relaxation, and the preservation of contractility by interrupted galvanic stimulation of the individual muscles. The conventional electrical bath was both harmful and a waste of time. After a period of correct treatment extending over some 18 months, further mitigation of the patient's disablement depended on artifice or operation, these measures being provided by the intervention of the orthopædic surgeon.

Mr. R. C. Elmstie (London) laid stress on the practical value of early diagnosis with reference to the immediate application of the principles of complete rest. He advocated the routine use of complete fixation of the recumbent patient on a frame or preferably a plaster-of-Paris "bed." At this stage all physio-therapeutic treatment was to be condemned. In the position adopted for fixation the correct posture for the limbs was of course essential. In the stage of later convalescence, muscle re-education should be begun and it was important to remember that all active movements were to be carried out over a very small range in order to avoid the risk of fatigue. Later on, for the lower limbs, suitable walking instruments were absolutely essential, and unless devised and ordered by experts often merited the criticism which their use evoked. In the later stages, for the preservation of nutrition of the limbs, the simplest measures 